07

\title{
Динамика влажности воздуха в концентраторном фотоэлектрическом модуле с устройством осушения
}

\author{
(ㄱ Д.А. Малевский, А.В. Малевская 『, П.В. Покровский, В.М. Андреев \\ Физико-технический институт им. А.Ф. Иоффре РАН, Санкт-Петербург, Россия \\ ๑ E-mail: amalevskaya@mail.ioffe.ru
}

Поступило в Редакцию 10 ноября 2020г.

В окончательной редакции 18 ноября 2020 г.

Принято к публикации 18 ноября 2020 г.

\begin{abstract}
Проведены исследования динамики изменения относительной влажности воздуха во внутренней среде концентраторного фотоэлектрического модуля с устройством осушения воздуха, заполненного влагопоглощающим материалом, выполненным из силикагеля. Разработана конструкция устройства осушения внутренней воздушной среды модуля с целью предотвращения выпадения конденсата на поверхности линзы Френеля, фотоэлектрического преобразователя и корпуса модуля. При неблагоприятных условиях окружающей среды (относительная влажность воздуха до 95\%) достигнуто снижение относительной влажности внутренней воздушной среды модуля до 25-55\% при циклическом изменении температуры внутри модуля от 15 до $45^{\circ} \mathrm{C}$ и увеличение дефицита точки росы до $10-25^{\circ} \mathrm{C}$.
\end{abstract}

Ключевые слова: концентраторный фотоэлектрический модуль, устройство осушения воздуха.

DOI: 10.21883/PJTF.2021.04.50648.18611

Солнечная фотоэнергетика является одним из наиболее перспективных направлений возобновляемой энергетики. Общая мировая мощность установленных солнечных фотоэнергосистем в мире составила к 2020г. более $630 \mathrm{GW}[1,2]$. Разработка и совершенствование технологии изготовления каскадных фотоэлектрических преобразователей (ФЭП), систем концентрирования солнечного излучения и систем слежения за Солнцем способствуют увеличению роли концентраторной солнечной фотоэнергетики [3].

Ускоренное развитие концентраторной солнечной фотоэнергетики обеспечивается путем увеличения эффективности ФЭП и концентраторных фотоэлектрических модулей (КФЭМ), а также путем увеличения энерговыработки солнечных электростанций на их основе [4-6].

При облучении КФЭМ солнечным излучением происходит нагрев воздушного пространства модуля, что приводит к увеличению давления в герметизированном модуле. Это может приводить к расфокусировке солнечного излучения вследствие прогиба концентраторов линз Френеля, также велика вероятность разгерметизации модуля. Сообщение КФЭМ с окружающей средой позволяет избежать перепадов давления в модуле при изменении температуры. Однако при неблагоприятных погодных условиях (при повышенной влажности воздуха и больших суточных перепадах температур) происходит увеличение влажности воздуха в КФЭМ, вследствие чего велик риск выпадения конденсата на внутреннюю поверхность линзы Френеля и ФЭП, что приведет к существенному рассеиванию солнечного излучения и снижению энерговыработки КФЭМ [7].

В настоящей работе выполнены исследования динамики изменения относительной влажности внутренней воздушной среды модуля с использованием макета
КФЭМ, установленного на системе слежения за Солнцем. Макет КФЭМ состоит из негерметизированного корпуса с прозрачной стеклянной фронтальной панелью. Внутри корпуса КФЭМ установлены датчики температуры и относительной влажности воздуха. На данном этапе испытаний фотоэлектрические преобразователи в макет КФЭМ не помещались. Измерения параметров внутренней воздушной среды КФЭМ проводились при неблагоприятных погодных условиях, при которых увеличивается риск выпадения конденсата на внутренних поверхностях КФЭМ. Относительная влажность окружающей среды составляла 65-95\% при температуре окружающей среды $10-30^{\circ} \mathrm{C}$. При помещении негерметизированного КФЭМ в данную среду наблюдалось увеличение относительной влажности его внутреннего воздушного пространства до 60-90\% при температуре внутри модуля $10-35^{\circ} \mathrm{C}$ в течение нескольких часов (кривая 1 на рис. 1). Для анализа параметров работы КФЭМ выполнен расчет дефицита точки росы, показывающий разницу температуры воздушного пространства модуля и точки росы, который составил $0.5-5^{\circ} \mathrm{C}$ (кривая 2 на рис. 1). Малые значения дефицита точки росы свидетельствуют об увеличении риска выпадения конденсата в модуле даже при небольшом быстром снижении температуры окружающей среды, например при порывах ветра или дожде.

Снизить влажность воздуха в модуле и предотвратить возникновение конденсата возможно при включении в конструкцию КФЭМ устройства осушения воздуха [8].

В настоящей работе проведена разработка конструкции устройства осушения и выполнены исследования динамики изменения относительной влажности внутреннего воздушного пространства КФЭМ (с подсоединен- 


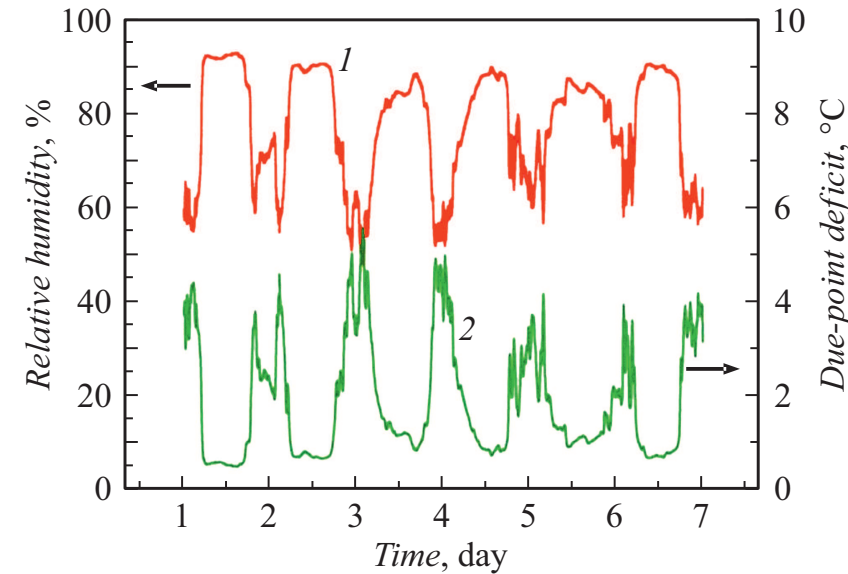

Pис. 1. Динамика изменения относительной влажности воздуха и дефицита точки росы во внутреннем воздушном пространстве КФЭМ при неблагоприятных погодных условиях, характеризующихся высокой влажностью окружающей среды (до 95\%). 1 - относительная влажность воздуха в КФЭМ, 2 - дефицит точки росы.

ным к КФЭМ устройством осушения) при изменении температуры и влажности окружающей среды.

Разработанная конструкция устройства осушения воздуха включает емкость с перегородками, образующими зигзагообразный воздушный канал от входного до выходного отверстий. Объем емкости заполнен гранулированным влагопоглощающим материалом из силикагеля с размером гранул $3-5 \mathrm{~mm}$, что обеспечивает свободное движение воздуха по воздушному каналу устройства осушения. Объем осушителя соединен через гибкую герметичную подводку с объемом КФЭМ.

Принцип работы системы осушения заключается в следующем. При снижении температуры воздуха в КФЭМ происходит уменьшение давления во внутреннем воздушном пространстве КФЭМ и „всасывание“ воздуха в КФЭМ через устройство осушения из внешней среды. Движение влажного воздуха по зигзагообразному воздушному каналу обеспечивает его взаимодействие с гранулами силикагеля, что позволяет достигать высокой скорости и степени осушения воздуха, поступающего в КФЭМ. При увеличении температуры воздуха в КФЭМ, облучаемом солнцем, происходит повышение давления в КФЭМ, приводящее к движению осушенного теплого воздуха из внутреннего пространства модуля в устройство осушения. При длительном нагреве силикагеля теплым осушенным воздухом осуществляется его регенерация.

Проведены исследования динамики изменения относительной влажности воздуха на макете КФЭМ с подсоединенным к нему устройством осушения. При относительной влажности воздуха окружающей среды $40-95 \%$ и температуре $15-30^{\circ} \mathrm{C}$ (кривая 1 на рис. 2) в случае использования осушителя наблюдается снижение относительной влажности в модуле до 25-55\% при циклическом изменении температуры в объеме КФЭМ от 15 до $45^{\circ} \mathrm{C}$ (кривая 2 на рис. 2). Дефицит точки росы составил $10-25^{\circ} \mathrm{C}$ (кривая 3 на рис. 2), что позволяет избежать выпадения конденсата на внутренних поверхностях КФЭМ. При длительном ухудшении погодных условий (после четвертого дня испытаний в условиях повышенной до 95\% влажности) наблюдается увеличение относительной влажности воздуха в модуле до $70 \%$ при температуре в модуле $15^{\circ} \mathrm{C}$, что ведет к снижению дефицита точки росы до $5^{\circ} \mathrm{C}$. Однако условия длительной повышенной влажности являются нехарактерными для климатических зон, использующих концентраторные фотоэнергосистемы. Тем не менее даже при таких погодных условиях использование устройства осушения воздуха позволяет избежать выпадения конденсата внутри модуля, что обеспечивает увеличение энерговыработки КФЭМ.

Для сравнительного анализа работы устройства осушения воздуха проведены измерения динамики изменения относительной влажности воздуха в КФЭМ при стандартных условиях окружающей среды: относительная влажность воздуха $50-70 \%$, температура $20-22^{\circ} \mathrm{C}$. Исследования проведены на КФЭМ, установленном в лабораторном помещении на стенде имитации условий окружающей среды. Стенд имитации включает имитатор солнечного излучения, состоящий из двух галогеновых ламп мощностью по $300 \mathrm{~W}$ с отражателями, систему обдува для имитации ветра и источник воздуха с повышенной относительной влажностью. Сначала КФЭМ подвергался циклическому (с интервалом $1 \mathrm{~h}$ ) облучению на имитаторе солнечного излучения. В результате каждого цикла воздух в корпусе модуля нагревался до температуры $65^{\circ} \mathrm{C}$ и охлаждался до $35^{\circ} \mathrm{C}$ при выключении имитатора. Значения относительной влажности воздуха в КФЭМ с осушителем и без него в этом режиме близки

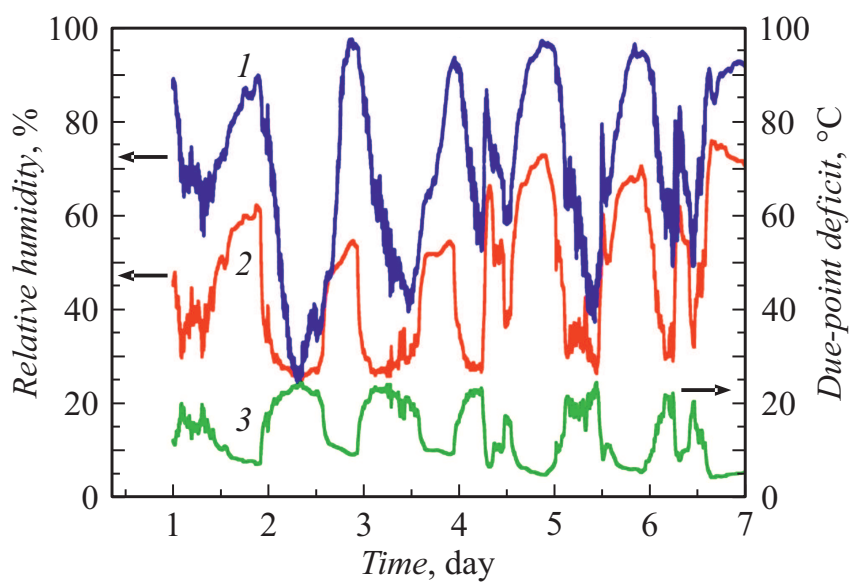

Рис. 2. Динамика изменения относительной влажности воздуха и дефицита точки росы во внутреннем воздушном пространстве КФЭМ с устройством осушения воздуха в натурных условиях. 1 - относительная влажность воздуха окружающей среды, 2 - относительная влажность воздуха в КФЭМ, 3 дефицит точки росы внутри КФЭМ. 


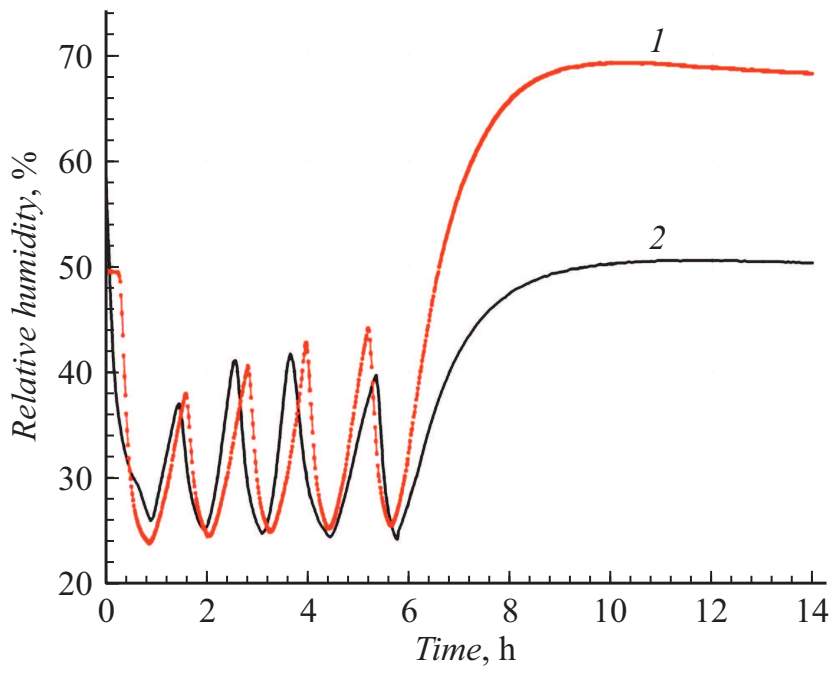

Pис. 3. Динамика изменения относительной влажности воздуха внутри КФЭМ, установленного на стенде имитации условий окружающей среды. 1 - в КФЭМ без осушителя, $2-$ в КФЭМ с осушителем.

по значению и составляют $25-45 \%$ в течение первых $6 \mathrm{~h}$ (рис. 3). На следующем этапе в периоде времени от 6 до $14 \mathrm{~h}$ имитатор солнечного излучения был отключен, что привело к увеличению относительной влажности внутри КФЭМ с осушителем воздуха до 50\% при температуре в модуле $20-22^{\circ} \mathrm{C}$, а в КФЭМ без осушителя- до $70 \%$ при той же температуре (рис. 3). Таким образом, использование осушителя воздуха обеспечило уменьшение на $20 \%$ относительной влажности воздуха в КФЭМ и предотвращение выпадения конденсата внутри КФЭМ с осушителем.

Результатом проведенных исследований является разработка устройства осушения внутреннего воздушного пространства КФЭМ, которое позволяет избежать выпадения конденсата внутри модуля. Достигнуто снижение относительной влажности внутренней воздушной среды КФЭМ до 25-55\% при изменении температуры внутри модуля от 15 до $45^{\circ} \mathrm{C}$ и увеличение дефицита точки росы до $10-25^{\circ} \mathrm{C}$ при относительной влажности окружающей среды, достигающей 95\%.

\section{Конфликт интересов}

Авторы заявляют, что у них нет конфликта интересов.

\section{Список литературы}

[1] IRENA: renewable energy statistics 2020 (International Renewable Energy Agency (IRENA), Abu Dhabi, 2020).

[2] Global market outlook for solar power/2020-2024. $\mathrm{https} / /$ www.solarpowereurope.org/global-market-outlook2020-2024
[3] Concentrator photovoltaics, ed. by A. Luque, V. Andreev. Springer Ser. in Optical Sciences (Springer, Berlin-Heidelberg, 2007), vol. 130.

[4] Н.А. Паханов, В.М. Андреев, М.З. Шварц, О.П. Пчеляков, Автомерия, 54 (2), 93 (2018). DOI: 10.15372/AUT20180211

[5] Solar cells: from materials to device technology, ed. by S.K. Sharma, K. Ali (Springer International Publ, 2020).

[6] Д.А. Малевский, П.В. Покровский, В.Р. Ларионов, А.В. Малевская, В.М. Андреев, Письма в ЖТФ, 46 (11), 11 (2020).

[7] J. Amajama, D.E. Oku, J. Sci. Eng. Res., 3 (4), 126 (2016).

[8] A. Gombert, J. Stor, C. Taliercio, Patent US2016003497 (07.01.2016). 